\title{
Pengaruh Pertumbuhan Ekonomi Terhadap Kemiskinan di Kabupaten Aceh Timur
}

\author{
Safuridar \\ Dosen Fakultas Ekonomi, Universitas Samudra \\ safuridar@gmail.com
}

\begin{abstract}
This study aims to determine the effect of economic growth on poverty in East Aceh. The data used in this study is secondary data obtained from the results of direct research both from BPS Kabupaten Aceh Timur and from the website of BPS. The data obtained were analyzed by using simple linear regression equation, coefficient of determination and t test. The result revelead that $\mathrm{Y}=$ 166.859 - 0,055X. 166,859 people are the number of poor people in East Aceh which is not influenced by economic growth. Furthermore, the regression coefficient $b$ of -0.055 indicates that the variable of economic growth negatively affect poverty and if economic growth is increased by $1 \%$, it will decrease poverty by $0,055 \%$. Coefficient of determination R2 equal to 0,776 or equal to $77,6 \%$, meaning that the influence of economic growth variable to poverty is $77.6 \%$ and the remaining $22.4 \%$ is influenced by other variables that are not examined in this study. The hypothesis that the economic growth has negative effect to poverty in East Aceh is acceptable. This is in accordance with the result of regression equation with negative economic growth coefficient is 0,055 and t-table <ttable is $-5,263<1,895$. Therefore, it can be concluded that the economic growth have both negative and significant effect to poverty in East Aceh.
\end{abstract}

Keywords: PBRB and Poverty

\section{ABSTRAK}

Penelitian ini dilakukan bertujuan untuk mengetahui pengaruh pertumbuhan ekonomi terhadap kemiskinan di Kabupaten Aceh Timur. Data yang digunakan dalam penelitian ini adalah data sekunder yang diperoleh dari hasil penelitian langsung baik dari BPS Kabupaten Aceh Timur maupun dari website BPS. Data yang diperoleh dianalisis dengan menggunakan persamaan regresi linier sederhana, koefisien determinasi dan uji t.Hasil penelitian diperoleh persamaan $Y=166.859-0,055 X$ dapat dijelaskan bahwa konstanta sebesar 166.859 jiwa adalah jumlah penduduk miskin di Kabupaten Aceh Timur yang tidak dipengaruhi oleh pertumbuhan ekonomi. Selanjutnya koefisien regresi b sebesar -0,055 menunjukkan bahwa variabel pertumbuhan ekonomi 
berpengaruh negatif terhadap kemiskinan dan bila pertumbuhan ekonomi ditingkatkan sebesar $1 \%$ maka akan menurunkan kemiskinan sebesar $0,055 \%$.Koefisien determinasi $\mathrm{R}^{2}$ sebesar 0,776 atau sebesar $77,6 \%$ artinya pengaruh variabel pertumbuhan ekonomi terhadap kemiskinan adalah $77,6 \%$ dan sisanya sebesar $22,4 \%$ dipengaruhi oleh variabel lain yang tidak diteliti dalam penelitian ini.Hipotesis yang menyatakan pertumbuhan ekonomi bepengaruh negatif terhadap kemiskinan di Kabupaten Aceh Timur dapat diterima. Hal ini sesuai dengan hasil persamaan regresi dengan koefisien pertumbuhan ekonomi bernilai negatif yaitu 0,055 dan $t_{\text {hitung }}<t_{\text {tabel }}$ yaitu $-5,263$ $<$ 1,895 dan dapat dinyatakan bahwa pertumbuhan ekonomi berpengaruh negatif dan signifikan terhadap kemiskinan di Kabupaten Aceh Timur.

Kata Kunci : PBRB dan Kemiskinan

\section{PENDAHULUAN}

Pertumbuhan ekonomi nasional tidak terlepas dari pertumbuhan ekonomi daerah. Dalam skala regional, pertumbuhan ekonomi dihitung dari perkembangan nilai Produk Domestik Regional Bruto (PDRB) selam periode pembangunan tertentu, baik secara riil maupun secara nominal. Produk Domestik regional Bruto (PDRB) merupakan salah satu indikator pertumbuhan ekonomi suatu negara, wilayah, atau suatu daerah. Sasaran pembangunan nasional adalah menurunkan tingkat kemiskinan. Kemiskinan merupakan salah satu penyakit dalam ekonomi, sehingga harus disembuhkan atau paling tidak dikurangi. Permasalahan kemiskinan memang merupakan permasalahan yang kompleks dan bersifat multidimensional. Oleh karena itu, upaya pengentasan kemiskinan harus dilakukan secara komprehensif, mencakup berbagai aspek kehidupan masyarakat, dan dilaksanakan secara terpadu.

Istilah kemiskinan muncul ketika seseorang atau sekelompok orang tidak mampu dalam mencukupi kebutuhan ekonomi yang dianggap sebagai kebutuhan minimal dari standar hidup tertentu. Dalam arti proper, kemiskinan dipahami sebagai keadaan kekurangan uang dan barang untuk menjamin kelangsungan hidup. Dalam arti luas, kemiskinan adalah suatu konsep yang 
memiliki dimensi, yaitu: 1) kemiskinan (proper), 2) ketidakberdayaan (powerless), 3) kerentanan menghadapi situasi darurat (state of emergency).

Penanggulangan kemiskinan merupakan agenda dan prioritas pembangunan nasional. Berbagai kebijakan, strategi dan kegiatan yang dilakukan dalam penanggulangan kemiskinan yang bersifat langsung maupun tidak langsung telah dilaksanakan baik dalam skala nasional maupun lokal. Selama ini kebijakan dan strategi pemenuhan kebutuhan masyarakat tersebut dilakukan melalui pelaksanaan proyek dan atau program yang seringkali penyaluran dan pembinaan sumber dananya sangat terbatas. Menanggulangi dan mengentaskan kemiskinan bukanlah usaha yang mudah dan sederhana, tetapi harus dilakukan dengan perencanaan yang terintegrasi dan terkoordinir dengan baik dengan bermacam-macam kebijakan yang harus tercermin dalam setiap kebijakan pemerintah dan dilakukan secara bersama-sama oleh pemerintah dan masyarakat dalam waktu yang relatif panjang dan berkelanjutan.

Kemiskinan di Kabupaten Aceh Timur saat ini merupakan masalah yang serius. Adanya pengemis dan rumah-rumah kurang layak huni di pinggiran kota yang terjadi selama ini belum dapat teratasi. Berdasarkan latar belakang, maka masalah yang dikemukakan dalam penulisan ini adalah seberapa besar pengaruh pertumbuhan ekonomi terhadap tingkat kemiskinan di Kabupaten Aceh Timur.Adapun tujuan dalam penelitian ini adalah untuk mengetahui dan menganalisis pengaruh pertumbuhan ekonomi terhadap kemiskinan di Kabupaten Aceh Timur.

\section{LANDASAN TEORITIS}

\section{Pengertian Pertumbuhan Ekonomi}

Menurut (Todaro, 2006), pertumbuhan ekonomi adalah kekaikan kapasitas dalam jangka panjang dari negara yang bersangkutan untuk menyediakan berbagai barang ekonomi kepada penduduknya yang ditentukan 
oleh adanya kemajuan atau penyesuaian-penyesuaian teknologi, institusional (kelembagaan), dan ideologis terhadap berbagai tuntutan keadaan yang ada. Pertumbuhan ekonomi menurut (Kunarjo: 2005) "adalah situasi yang menggambarkan produk domestik bruto per kapita suatu negara yang mengalami peningkatan". Para ekonom lainnya seperti (Nanga: 2006), mengungkapkan "secara umum, pertumbuhan ekonomi didefinisikan sebagai peningkatan dalam kemampuan dari suatu perekonomian dalam memproduksi barang-barang dan jasa-jasa”.

Menurut ( Kuncoro : 2005) menyatakan bahwa pada dasarnya ada empat faktor yang mempengaruhi pertumbuhan ekonomi, yaitu:

1. Jumlah penduduk,

2. Jumlah stok barang modal,

3. Luas tanah dan kekayaan alam,

4. Tingkat ekonomi yang digunakan.

(Kuncoro: 2005), indikator yang digunakan untuk menghitung tingkat pertumbuhan ekonomi:

1. Tingkat Pertumbuhan PDB (Produk Domestik Bruto)

2. Tingkat Pertumbuhan PNB (Produk Nasional Bruto)

Dalam praktek angka, PNB kurang lazim dipakai, yang lebih populer dipakai adalah PDB, karena angka PDB hanya melihat batas wilayah, terbatas pada negara yang bersangkutan.

\section{Teori-Teori yang Berkaitan dengan Pertumbuhan Ekonomi}

Menurut (Arsyad : 2005) menjelaskan dan menguraikan dengan berbagai teori yang berkaitan dengan pertumbuhan ekonomi, sebagai berikut:

a. Teori Pertumbuhan Klasik

Menurut pandangan ahli-ahli ekonomi klasik, ada tiga faktor yang mempengaruhi pertumbuhanekonomi, yaitu:

1. Jumlah penduduk 
2. Luas tanah dan kekayaan

3. Tingkat Teknologi yang digunakan

Teori ini menekankan tentang pentingnya faktor-faktor produksi dalam menaikkan pendapatan Nasional dan mewujudkan pertumbuhan. Akan tetapi yang terutama diperhatikan ahli ekonomi klasik adalah peranan tenaga kerja. Menurut mereka tenaga kerja yang berlebihan akan mempengaruhi pertumbuhan ekonomi.

b. Teori Schumpeter

Teori ini menekankan tentang pentingnya pengusaha dalam mewujudkan pertumbuhan ekonomi, bahwa para pengusaha merupakan golongan yang akan terus menerus membuat pembaharuan atau inovasi dalam kegiatan ekonomi. Inovasi tersebut meliputi memperkenalkan barang baru, mempertinggi efisiensi cara memproduksi dalam menghasilkan suatu barang, memperluas pasar sesuatu barang ke pasaran yang baru, mengembangkan sumber bahan mentah yang baru dan mengadakan perubahan-perubahan dalam organisasi dengan tujuan mempertinggi keefisienan kegiatan perusahaan.

c. Teori Harrod - Domar

Teori ini bertujuan untuk menrangkan syarat yang harus dipenuhi supaya suatu perekonomian dapat mencapai pertumbuhan yang teguh atau "steady growth" dalam jangka panjang. Analisis Harrod - Domar menggunakan pemisalan sebagai berikut:

1. Barang modal telah mencapai kapasitas penuh.

2. Tabungan adalah proporsional dengan pendapatan Nasional.

3. Rasio modal produk (capital output ratio) tetap nilainya.

4. Perekonomian terdiri dari dua sektor.

Teori Harrod menunjukkan peranan investasi sebagai faktor yang menimbulkan pertambahan pengeluaran agregat. Teori ini pada dasarnya 
menekankan peranan segi permintaan dalam mewujudkan penerimaan negara.

d. Teori Neo Klasik

Melalui kajian empircal theory ini menunjukkan bahwa perkembangan teknologi dan peningkatan kemahiran masyarakat merupakan faktor yang terpenting yang mewujudkan pertumbuhan ekonomi.Para ahli ekonomi menganggap faktor produksi sebagai kekuatan utama yang mempengaruhi pertumbuhan. Tinggi rendahnya laju pertumbuhan ekonomi merupakan konsekuensi dari pertumbuhan yang terjadi di dalam faktor produksi tersebut.

\section{Faktor-Faktor Yang Mempengaruhi Pertumbuhan Ekonomi}

Faktor utama dari pertumbuhan ekonomi adalah (1) akumulasi modal, (2) pertumbuhan penduduk, dan (3) kemajuan-kemajuan di bidang teknologi (Todaro, 2004). Pertumbuhan ekonomi dihasilkan dari interaksi-interaksi faktor-faktor produksi. Output barang dan jasa yang dihasilkan oleh suatu perekonomian bergantung pada kuantitas input yang tersedia seperti kapital dan tenaga kerja, dan produktivitas dari input tersebut.

Menurut (Todaro :2006), ada tiga faktor utama dalam pertumbuhan ekonomi, yaitu:

1. Akumulasi modal termasuk semua investasi baru yang berwujud tanah (lahan), peralatan fiskal, dan sumber daya manusia (human resources). Akumulasi modal akan terjadi jika ada sebagian dari pendapatan sekarang ditabung yang kemudian diinvestasikan kembali dengan tujuan untuk memperbesar output di masa-masa mendatang. Investasi juga harus disertai dengan investasi infrastruktur, yakni berupa jalan, listrik, air bersih, fasilitas sanitasi, fasilitas komunikasi, demi menunjang aktivitas ekonomi produktif. Investasi dalam pembinaan sumber daya manusia 
bermuara pada peningkatan kualitas modal manusia, yang pada akhirnya dapat berdampak positif terhadap angka produksi.

2. Perumbuhan penduduk dan angkatan kerja. Pertumbuhan penduduk dan hal-hal yang berhubungan dengan kenaikan jumlah angka kerja (labor force) secara tradisional telah dianggap sebagai faktor yang positif dalam merangsang pertumbuhan ekonomi. Artinya, semakin banyak angkatan kerja semakin produktif tenaga kerja, sedangkan semakin banyak penduduk akan meningkatkan potensi pasar domestiknya.

3. Kemajuan teknologi. Kemajuan teknologi disebabkan oleh teknologi caracara baru dan cara-cara lama yang diperbaiki dalam melakukan pekerjaanpekerjaan tradisional. Ada 3 klasifikasi kemajuan teknologi, yakni:

a. Kemajuan teknologi yang bersifat netral, terjadi jika tingkat output yang dicapai lebih tinggi pada kuantitas dan kombinasi-kombinasi input yang sama.

b. Kemajuan teknologi yang bersifat hemat tenaga kerja (labor saving) atau hemat modal (capital saving), yaitu tingkat output yang lebih tinggi bisa dicapai dengan jumlah tenaga kerja atau input modal yang sama.

c. Kemajuan teknologi yang meningkatkan modal, terjadi jika penggunaan teknologi tersebut memungkinkan kita memanfaatkan barang modal yang ada secara lebih produktif.

\section{Pengertian Kemiskinan}

(Michael P. Todaro: 2006) mengemukakan kemiskinan absolut, yaitu sejumlah penduduk yang tidak mampu mendapatkan sumber daya yang cukup untuk memenuhi kebutuhan dasar. Penduduk tersebut hidup di bawah tingkat pendapatan riil minimum tertentu atau di bawah garis kemiskinan.

Menurut Biro Pusat Statistik (www.bps.go.id), yang dikategorikan sebagai penduduk miskin adalah penduduk yang tidak mampu memnuhi 
kebutuhan minimum 2.100 kalori per kapita per hari ditambah dengan kebutuhan minimum non-makanan yang merupakan kebutuhan dasar seseorang yang meliputi kebutuhan dasar untuk papan, sandang, sekolah, transportasi serta kebutuhan rumah tangga dan individu yang mendasar lainnya. Kemiskinan memberi gambaran situasi serba kekurangan seperti terbatasnya modal yang dimiliki, rendahnya pengetahuan dan keterampilan, rendahnya produktivitas, rendahnya pendapatan, lemahnya nilai tukar hasil produksi orang miskin dan terbatasnya kesempatan berperan serta dalam pembangunan. Ketidak berdayaan penduduk miskin, disebabkan mereka tidak memiliki aset sebagai sumber pendapatan juga karena struktur sosial ekonomi tidak membuka peluang orang miskin ke luar dari lingkungan kemiskinan yang tak berujung pangkal.

(Mankiw : 2005) menyatakan bahwa untuk daerah perkotaan kebutuhan minimal perkapita setara dengan $420 \mathrm{~kg}$ beras per tahunnya, dan untuk daerah perdesaan 320 kg. kemiskinan relatif berkaitan dengan distribusi pendapatan yang mengukur ketidakmerataan. Dalam kemiskinan relatif, seseorang yang telah mampu memenuhi kebutuhan minimumnya belum tentu disebut tidak miskin, karena apabila dibandingkan dengan penduduk sekitarnya ia memiliki pendapatan yang lebih rendah.

(Asfia Murni :2006), kemiskinan, khususnya kemiskinan di kota erat kaitannya dengan langkanya peluang kerja yang produktif. Penduduk, baik pendatang (urbanis) maupun penduduk kota yang baru masuk angkatan kerja, dengan kemampuan yang mereka miliki menciptakan kesempatan kerja dengan memanfaatkan kehidupan kota. Dipandang dari sudut ekonomi, kemiskinan dapat dilihat dari beberapa sisi, yaitu:

1. Secara makro, kemiskinan muncul karena adanya ketidaksamaan pola kepemilikan sumberdaya yang menimbulkan distribusi yang timpang. Penduduk miskin memiliki sumberdaya terbatas dan kualitasnya rendah. 
2. Kemiskinan muncul akibat perbedaan dalam kualitas sumberdaya manusia. Kualitas sumberdaya manusia yang rendah berarti produktivitasnya rendah, yang pada gilirannya upahnya rendah. Rendahnya kualitas sumberdaya manusia ini karena rendahnya tingkat pendidikan, nasib yang kurang beruntung, adanya diskriminasi, atau karena keturunan.

3. Kemiskinan muncul akibat perbedaan akses dalam modal.

4. Di daerah perkotaan, derasnya arus migran masuk juga memberi dampak terhadap semakin banyaknya penduduk dalam kategori miskin. Di daerah perkotaan, terputusnya akses pengairan di sebagian subak-subak, berdampak pada perubahan perilaku petani. Apabila petani tidak dapat segera mengantisipasi perubahan tersebut, mereka akan kesulitan untuk melakukan aktivitas produktif di pertanian. Optimalisasi lahan yang telah terputus akses pengairannya perlu segera dipolakan agar kemanfaatannya oleh petani dan masyarakat perkotaan dapat dirasakan.

(Sahdan : 2006) kemiskinan merupakan persoalan yang kompleks, maka cara penanggulangan kemiskinan pun membutuhkan analisis yang tepat, melibatkan semua komponen permasalahan, dan diperlukan strategi penanganan yang tepat, berkelanjutan dan tidak bersifat temporer. Sejumlah variabel dapat dipakai untuk melacak persoalan kemiskinan, dan dari variabel itu dihasilkan serangkain strategi kebijakan penanggulangan kemiskinan yang tepat sasaran dan berkesinambungan.

\section{Pengaruh Pertumbuhan Ekonomi Terhadap Kemiskinan}

(Mankiw : 2005), dengan adanya pertumbuhan ekonomi berarti terdapat peningkatan produksi sehingga menambah lapangan pekerjaan yang ada pada akhirnya akan mengurangi kemiskinan. (Sukirno : 2005) menyatakan bahwa pertumbuhan ekonomi merupakan syarat keharusan (necessary condition) bagi pengurangan kemiskinan. Adapun syarat kecukupannya 
(sufficient condition) ialah bahwa pertumbuhan tersebut efektif dalam mengurangi kemiskinan. Artinya, pertumbuhan tersebut hendaknya menyebar di setiap golongan pendapatan,termasuk golongan penduduk miskin (growth with equity).

(Kuncoro: 2005) mengatakan bahwa pertumbuhan pada sektor jasa di pedesaan menurunkan kemiskinan di semua sektor dan lokasi. Namun pertumbuhan jasa di perkotaan memberikan nilai elastisitas kemiskinan yang tinggi dari semua sektor kecuali pertanian perkotaan. Selain itu pertumbuhan pertanian di pedesaan memberikan dampak yang besar terhadap penurunan kemiskinan di sektor pertanian pedesaan, yang merupakan kontributor terbesar kemiskinan di Indonesia.

\section{Hubungan Tingkat Kemiskinan dengan Pertumbuhan Ekonomi}

Menurut (Siregar dan Wahyuniarti : 2008), pertumbuhan ekonomi merupakan indikator untuk melihat keberhasilan pembangunan dan merupakan syarat bagi pengurangan tingkat kemiskinan. Syaratnya adalah hasil dari pertumbuhan ekonomi tersebut menyebar di setiap golongan masyarakat, termasuk di golongan penduduk miskin.

Selanjutnya penelitian yang dilakukan (Kuncoro : 2005), menemukan bahwa terdapat hubungan yang negatif antara pertumbuhan ekonomi dan tingkat kemiskinan. Kenaikan pertumbuhan ekonomi akan menurunkan tingkat kemiskinan. Hubungan ini menunjukkan pentingnya mempercepat pertumbuhan ekonomi untuk menurunkan tingkat kemiskinan.

\section{METODE}

Untuk menganalisa data agar sesuai dengan tujuan penelitian ini, guna mengetahui pengaruh perkembangan tingkat pertumbuhan ekonomi terhadap tingkat kemiskinan di Kabupaten Aceh Timur dengan menggunakan rumus regresi linier sederhana, yaitu: (Supranto: 2006) 
$\mathrm{Y}=\mathrm{a}+\mathrm{bX}$

$\mathrm{Y}=$ Tingkat Kemiskinan

$\mathrm{X}=$ Tingkat Pertumbuhan Ekonomi

$\mathrm{a}=$ Konstanta

$b=$ Koefisien Regresi

Pengujian hipotesis

Selanjutnya menguji hipotesis diterima atau tidak maka diuji dengan menggunakan rumus statistik yang dikemukakan oleh (Sudjana : 2002):

$$
t=\frac{r \sqrt{n-2}}{\sqrt{1-r^{2}}}
$$

Adapun rumusan hipotesisnya adalah:

$\mathrm{H}_{1}=\mathrm{o}$ terdapat pengaruh yang positif pertumbuhan ekonomi terhadap tingkat kemiskinan di Kabupaten Aceh Timur.

$\mathrm{H}_{\mathrm{o}}=\mathrm{o}$ tidak terdapat pengaruh pertumbuhan ekonomi terhadap tingkat kemiskinan di Kabupaten Aceh Timur.

Dimana $t=$ hasil hitung distribusi dari koefisien regresi dengan derajat kebebasan $\mathrm{dk}=(\mathrm{n}-1)$ sedangkan $\mathrm{n}$ adalah subjek yang diteliti. Untuk pengujian hipotesis tersebut digunakan taraf signifikan $\alpha=0,05$ kaedah keputusannya:

$\mathrm{H}_{1}$ : diterima apabila $t_{\text {hitung }}>\mathrm{t}_{\text {tabel }}$ pada $\alpha=0,05$

$\mathrm{H}_{1}$ : ditolak apabila $\mathrm{t}_{\text {hitung }}<\mathrm{t}_{\text {tabel }}$ pada $\alpha=0,05$ 


\section{HASIL PENELITIAN DAN PEMBAHASAN}

\section{Pertumbuhan Ekonomi menurut Sektor Lapangan Usaha}

Tabel Laju Pertumbuhan Sektor Ekonomi menurut Lapangan UsahaTahun 2007 - 2015 (dalam persen)

\begin{tabular}{|c|c|c|c|c|c|c|c|c|c|c|}
\hline No & Sektor & 2007 & $\begin{array}{l}200 \\
8\end{array}$ & $\begin{array}{l}200 \\
9\end{array}$ & 2010 & 2011 & 2012 & 2013 & 2014 & 2015 \\
\hline 1 & Pertanian & 2,75 & 1,85 & 0,82 & 1,74 & 1,35 & 5,21 & 6,12 & 5,17 & 3,32 \\
\hline 2 & $\begin{array}{l}\text { Pertambangan dan } \\
\text { Penggalian }\end{array}$ & 1,83 & 2,47 & 3,33 & 5,66 & 6,75 & 2,97 & 3,41 & 6,92 & 2,50 \\
\hline 3 & Industri Pengolahan & 2,65 & 3,59 & 4,49 & 3,76 & 4,41 & 7,71 & 5,32 & 3,17 & 3,01 \\
\hline 4 & $\begin{array}{l}\text { Listrik dan Air } \\
\text { Minum }\end{array}$ & 3,72 & 2,10 & 2,14 & 4,29 & 4,78 & 3,93 & 7,98 & 7,99 & 2,40 \\
\hline 5 & Bangunan & 4,15 & 3,78 & 4,34 & 3,84 & 4,29 & $\begin{array}{l}21,6 \\
3\end{array}$ & $\begin{array}{l}18,6 \\
6\end{array}$ & 11,73 & 4,13 \\
\hline 6 & $\begin{array}{l}\text { Perdagangan, } \\
\text { Hotel dan } \\
\text { Restoran }\end{array}$ & 3,81 & 4,57 & 4,31 & 5,82 & 5,87 & 11,71 & 5,84 & 1,57 & 2,59 \\
\hline 7 & $\begin{array}{l}\text { Pengangkutan dan } \\
\text { Komunikasi }\end{array}$ & 7,25 & 4,84 & 8,61 & 2,83 & 3,38 & 14,29 & 13,55 & 12,81 & 5,89 \\
\hline 8 & $\begin{array}{l}\text { Keuangan, } \\
\text { Persewaan dan } \\
\text { Jasa Perusahaan }\end{array}$ & 4,47 & 5,88 & 4,28 & $-13,92$ & 2,83 & 66,59 & 32,78 & 22,15 & 3,80 \\
\hline 9 & Jasa-jasa & 2,84 & 2,18 & 2,89 & 2,18 & 2,84 & 6,80 & 6,02 & 4,36 & 6,80 \\
\hline \multicolumn{2}{|c|}{$\begin{array}{l}\text { Pendapatan Domestik } \\
\text { Regional Bruto (PDRB) }\end{array}$} & 3,72 & 3,47 & 3,92 & 2,18 & 2,97 & $\begin{array}{l}12,5 \\
0\end{array}$ & 9,74 & 6,76 & 4,22 \\
\hline
\end{tabular}

Sumber: Badan Pusat Statistik Kabupaten Aceh Timur, tahun 2016

Seluruh sektor ekonomi mengalami pertumbuhan yang positif dengan level yang berbeda-beda. Demikian halnya dengan tahun 2009 dan 2010, perekonomian Kabupaten Aceh Timur diperkirakan mengalami pertumbuhan positif dan pada tahun 2013 hingga tahun 2015 terus mengalami penurunan.

Pertumbuhan ekonomi Kabupaten Aceh Timur ditinjau dari pertumbuhan PDRB tahun 2009 pertumbuhan Kabupaten Aceh Timur 
mengalami perlambatan hingga 3,92 persen, pada tahun 2010 pertumbuhan ekonomi Kabupaten Aceh Timur mengalami penurunan kembali hingga menjadi 2,18 persen. Tahun 2011 sedikit meningkat menjadi 2,97 persen dan tahun 2012 meningkat pesat sebesar 12,50 persen, akan tetapi tahun 2013 hingga tahun 2015 terus mengalami penurunan, karena terjadi pertumbuhan pendapatan masyarakat di Kabupaten Aceh Timur.

Sektor yang mengalami pertumbuhan tertinggi pada tahun 2010 adalah oleh sektor perdagangan, hotel dan restoran tahun 2010 tumbuh sebesar 5,82 persen. Pertumbuhan sektor perdagangan, hotel dan restoran di tahun 2010 relatif lebih tinggi dibandingkan tahun sebelumnya yang mencapai angka 4,31 persen. Pada tahun 2012 Aceh Timur cukup baik, dimana pendapatan tertinggi diperoleh pada sektor bangunan sebesar 21,63 persen keuangan persewaan dan jasa perusahaan sebesar 66,59 persen.

Sektor petambangan dan penggalian menempati posisi kedua pada tahun 2010 dengan pertumbuhan sebesar 5,66 persen, walaupun pertumbuhannya tinggi namun tidak mampu mendongkrak laju pertumbuhan ekonomi Aceh Timur. Ini menunjukkan, bahwa kontribusi yang rendah dari suatu sektor belum tentu dapat mendorong pertumbuhan ekonomi secara total walaupun pertumbuhannya relatif tinggi. Kemudian disusul oleh sektor listrik dan air minum tumbuh sebesar 4,29 persen dimana tahun sebelumnya hanya mampu tumbuh sebesar 2,14 persen.

Selanjutnya diikuti oleh sektor bangunan di tahun 2010 tumbuh sebesar 3,84 persen. Angka ini leboh rendah bila dibandingkan dengan tahun 2009 yang mencapai 4,34 persen. Sektor industri pengolahan pada tahun 2010 tumbuh sebesar 3,76 persen, memiliki pertumbuhan terbesar kelima sedangkan pada tahun 2009 sektor ini menempati posisi kedua, pertumbuhan ini lebih rendah dari tahun 2009 dimana pertumbuhannya mencapai 4,49 persen. Sektor perdagangan dan komunikasi yang mencapai 2,83 persen, padahal tahun sebelumnya sebesar 8,61 persen dan urutan ketujuh adalah 
sektor jasa-jasa tumbuh sebesar 2,18 persen dan lebih rendah dari tahun sebelumnya dimana tumbuh sebesar 2,89 persen.

Dua sektor terakhir, yakni sektor pertanian dan sektor keuangan, persewaan dan jasa perusahaan pada tahun 2010 mengalami pertumbuhan dibawah 2 persen. Sektor pertanian pada tahun memiliki sumbangan sektor cukup tinggi ternyata hanya mampu tumbuh sebesar 1,74 persen. Sedangkan pada tahun 2009 sektor pertanian tumbuh sebesar 0,82 persen. Kontraksi yang terjadi pada sub sektor kehutanan sebesar minus 1,72 persen, menyebabkan sektor ini turut andil terhadap rendahnya laju pertumbuhan di sektor pertanian.

Sektor keuangan, persewaan dan jasa perusahaan selalu mencapai pertumbuhan tertinggi, namun dominasi sektor ini pada tahun 2010 pertumbuhannya turun sangat drastis sehingga menyebabkan posisinya digantikan oleh sektor keuangan, perdagangan, hotel dan restoran. Rendahnya angka pertumbuhan sektor keuangan, persewaan dan jasa perusahaan akibat terjadinya kontraksi yang sangat tinggi pada sub sektor bank yaitu sebesar minus 37 persen, akibatnya pertumbuhan sektor ini juga anjlok hingga sebesar minus 13,92 persen. Angka pertumbuhan sektor keuangan, persewaan dan jasa perusahaan tersebut, lebih rendah dari tahun 2009 yang mencapai 4,28 persen.

\section{Tingkat Kemiskinan}

Kemiskinan merupakan kedaan dimana terjadi ketidakmampuan untuk memenuhi kebutuhan dasar seperti makanan, pakaian, tempat berlindung, pendidikan, dan kesehatan. Kemiskinan dapat disebabkan oleh kelangkaan alat pemenuh kebutuhan dasar, ataupun sulitnya akses terhadap pendidikan dan pekerjaan. Demikian halnya dengan penduduk Aceh Timur masih ada yang belum dapat memenuhi kebutuhan dasar dan masuk ke dalam kategori miskin yang dapat dilihat pada Tabel IV-4 berikut ini : 
Tabel.2 Persentase Kemiskinan di Kabupaten Aceh TimurTahun 2006 - 2015

\begin{tabular}{|l|l|l|l|}
\hline No & Tahun & $\begin{array}{l}\text { Jumlah Penduduk } \\
\text { Miskin }\end{array}$ & Persentase Kemiskinan \\
\hline 1 & 2006 & 92.800 & 29,83 \\
\hline 2 & 2007 & 92.200 & 29,53 \\
\hline 3 & 2008 & 84.900 & 27,10 \\
\hline 4 & 2009 & 76.220 & 22,89 \\
\hline 5 & 2010 & 68.300 & 19,55 \\
\hline 6 & 2011 & 66.500 & 18,45 \\
\hline 7 & 2012 & 66.700 & 18,01 \\
\hline 8 & 2013 & 65.400 & 17,28 \\
\hline 9 & 2014 & 64.400 & 16,67 \\
\hline 10 & 2015 & 63.000 & 15,95 \\
\hline
\end{tabular}

Sumber: Badan Pusat Statistik Kab. Aceh Timur, tahun 2016

Dari Tabel.2 IV-4 dapat diketahui persentase kemiskinan di Kabupaten Aceh Timur dari tahun 2006 hingga tahun 2015 mengalami penurunan. Tahun 2006 persentase kemiskinan sebesar 29,83 persen, tahun 2007 menurun menjadi sebesar 29,753 persen, kemudian pada tahun 2008 sebesar 27,10 persen, selanjutnya tahun 2009 menurun menjadi sebesar 22,89 persen yang berarti menurun sebesar 4,21\%, pada tahun 2010 sedikit menurun dari tahun sebelumnya yaitu menjadi sebesar 19,55 persen, selanjutnya tahun 2011 tingkat persentase kemiskinan menurun lagi menjadi 18,45 persen dan tahun 2012 menurun menjadi 18,01 persen, tahun 2013 sebesar 17,28\%, tahun 2014\% sebesar 16,67\% dan tahun 2015 sebesar 15,95\%. Dengan demikian persentase kemiskinan di Kabupaten Aceh Timur mengalami penurunan mulai dari tahun 2006 hingga 2015. 


\section{PEMBAHASAN}

Untuk mengetahui pengaruh pertumbuhan ekonomi terhadap kemiskinan di Kabupaten Aceh Timur digunakan program SPSS (Statistical Product Solution Service) versi 20.0 dengan hasil coefficientspersamaansebagai berikut :

$Y=166.859,090-0,055 X$

Dapat dijelaskan bahwa konstanta sebesar 166.859,090 adalah besarnya kemiskinan di Kabupaten Aceh Timur yang tidak dipengaruhi oleh pertumbuhan ekonomi. Selanjutnya koefisien regresi b sebesar -0,055 menunjukkan bahwa variabel pertumbuhan ekonomi berpengaruh negatif terhadap kemiskinan dan bila pertumbuhan ekonomi ditingkatkan sebesar $1 \%$ maka akan menurunkan kemiskinan sebesar 0,055\%.

Kemudian untuk melihat hubungan variabel bebas dan variabel terikat dapat dilihat pada tabel dibawah ini :

\section{Model Summary}

\begin{tabular}{|l|l|l|l|l|}
\hline Model & $R$ & $R$ Square & $\begin{array}{l}\text { Adjusted } \\
\text { Square }\end{array}$ & $\begin{array}{l}\text { Std. Error of the } \\
\text { Estimate }\end{array}$ \\
\hline 1 &, $881^{\mathrm{a}}$ &, 776 &, 748 & 5888,10723 \\
\hline
\end{tabular}

a. Predictors: (Constant), Pertumbuhan_Ekonomi

Dari Tabel diatas dapat diketahui koefisien korelasi $\mathrm{R}$ sebesar 0,881 atau sebesar $88,1 \%$ hubungan variabel pertumbuhan ekonomi dan kemiskinan. Nilai ini termasuk hubungan yang kuat karena sudah mendekati +1 . Selanjutnya nilai koefisien determinasi $R^{2}$ sebesar 0,776 atau sebesar $77,6 \%$ artinya pengaruh variabel pertumbuhan ekonomi terhadap kemiskinan adalah 77,6\% dan sisanya sebesar $22,4 \%$ dipengaruhi oleh variabel lain yang tidak diteliti dalam penelitian ini. 


\section{Pembuktian Hipotesis}

Pembuktian hipotesis dilakukan dengan:

$t_{\text {hitung }}<t_{\text {tabel }}$ yaitu $-5,263<1,895$ dan dapat dinyatakan bahwa pertumbuhan ekonomi berpengaruh negatif dan signifikan terhadap kemiskinan di Kabupaten Aceh Timur. Sehingga hipotesis yang menyatakan pertumbuhan ekonomi bepengaruh negatif terhadap kemiskinan di Kabupaten Aceh Timur dapat diterima. Hal ini didukung dengan hasil persamaan regresi dengan koefisien pertumbuhan ekonomi bernilai negatif yaitu 0,055.

\section{Simpulan}

1. Hasil penelitian diperoleh persamaan persamaan $Y=166.859-0,055 X$ dapat dijelaskan bahwa konstanta sebesar 166.859 jiwa adalah jumlah penduduk miskin di Kabupaten Aceh Timur yang tidak dipengaruhi oleh pertumbuhan ekonomi. Selanjutnya koefisien regresi b sebesar -0,055 menunjukkan bahwa variabel pertumbuhan ekonomi berpengaruh negatif terhadap kemiskinan dan bila pertumbuhan ekonomi ditingkatkan sebesar 1\% maka akan menurunkan kemiskinan sebesar 0,055\%.

2. Koefisien determinasi $R^{2}$ sebesar 0,776 atau sebesar $77,6 \%$ artinya pengaruh variabel pertumbuhan ekonomi terhadap kemiskinan adalah $77,6 \%$ dan sisanya sebesar $22,4 \%$ dipengaruhi oleh variabel lain yang tidak diteliti dalam penelitian ini.

3. Hipotesis yang menyatakan pertumbuhan ekonomi bepengaruh negatif terhadap kemiskinan di Kabupaten Aceh Timur dapat diterima. Hal ini sesuai dengan hasil persamaan regresi dengan koefisien pertumbuhan ekonomi bernilai negatif yaitu 0,055 dan $t_{\text {hitung }}<t_{\text {tabel }}$ yaitu -5,263 $<1,895$ dan dapat dinyatakan bahwa pertumbuhan ekonomi berpengaruh negatif dan signifikan terhadap kemiskinan di Kabupaten Aceh Timur. 


\section{PUSTAKA ACUAN}

Adji, Wahyu. 2005. Uang, Sistem Keuangan dan Ekonomi, Jakarta: Erlangga.

Arsyad. 2005. Pengantar Perencanaan Pembangunan Ekonomi Daerah, Yogyakarta: BPFE.

Amijaya. 2008. Pengaruh Ketidakmerataan Distribusi Pendapatan, Pertumbuhan Ekonomi, dan Pengangguran Terhadap Tingkat Kemiskinan Di Indonesia Tahun 2003 - 2004. Skripsi. Universitas Diponegoro, Semarang.

Badan Pusat Statistik. 2012. Aceh Timur dalam Angka. Idi Rayeuk Kabupaten Aceh Timur.

BAPPEDA Aceh Timur kerjasama dengan Badan Pusat Statistik Aceh Timur, Aceh Timur dalam Angka. Idi Rayeuk.

Hall, Anthony dan James Midgley, 2004, Social Policy for Development, Sage Publications Ltd., London.

Friedmann, John, 1999, Urban Poverty in Latin America, Some Theoritical Considerations, Development Dialogue, Vol.1, Hammarskjold Foundation.

Kuncoro, Mudrajad, 2005, Ekonomi Pembangunan: Teori, Masalah dan Kebijakan, Yogyakarta: UPP AMP YKPN.

Kunarjo, 2005, Glossarium Ekonomi, Jakarta: Rineka Cipta.

Mankiw, N. Gregory, 2005, Teori Makro Ekonomi, Jakarta: Erlangga.

Murni, Asfia. 2006. Ekonomi Makro, Bandung: Refika Aditama.

Nanga, Muana, 2004, Makro Ekonomi, Jakarta: PT. Raja Grafindo Perkasa.

Sutrisno, 1997, Dasar-Dasar Keuangan Negara, Yogyakarta: BPFE-UGM.

Sahdan, 2006, Economic Growth and Pproperty Reduction in Indonesia.

Saputra, Whisnu Adhi, 2011, Analisis Pengaruh Jumlah Penduduk, PDRB, IPM, Pengangguran terhadap Tingkat Kemiskinan di Kabupaten/Kota Jawa Tengah. Skripsi. Universitas Diponegoro. 
Sukirno, Sadono, 2005, Makro Ekonomi Moderen, Jakarta: PT. Raja Grafika Persada.

Sudjana, 2002, Metode Statistika. Bandung: Taksito.

Supranto, J, 2006. Statistik Teori dan Aplikasi, Jakarta: Erlangga.

Todaro, Michael, P., 2006, Pembangunan Ekonomi di Dunia Ketiga, Jakarta: Erlangga.

Tarigan, Robinson, 2006, Ekonomi Regional: Teori dan Aplikasi, Jakarta: Bumi Aksara. 